separated crystals were collected by filtration. Recrystallization from acetone gave $1.58 \mathrm{~g}(48 \%)$ of product 5 as needles, mp $214-215^{\circ}$, undepressed on admixture with an authentic sample prepared according to the literature. ${ }^{5,7)}$ Admixture of this compound (5) with a sample obtained from diketene ${ }^{10}$ showed no melting point depression.

Ethyl 4,6-Dimethyl-2(1H)-pyridone-5-carboxylate (6)-A mixture of PPA (10 g), ethyl acetoacetate $(5.2 \mathrm{~g})$ and the amide $1(2.0 \mathrm{~g})$ was heated at $110^{\circ}$ with stirring for $3 \mathrm{hr}$. The reaction mixture was poured onto ice and neutralized with $10 \% \mathrm{Na}_{2} \mathrm{CO}_{3}$. Precipitated crystals (6) were filtered off and the filtrate was extracted with AcOEt. The organic layer was concentrated and the residue was chromatographed on a silica gel column. Elution with hexane-- $\mathrm{CHCl}_{3}(3: 1)$ gave crystals. Crystals were combined and recrystallized from acetone to afford $0.96 \mathrm{~g}(25 \%)$ of product 6 as needles, mp $138-139^{\circ}\left(\right.$ lit. $\left.^{13)} \mathrm{mp} 138-139^{\circ}\right)$.

3-Acetyl-4-hydroxy-6-methyl-2(1H)-pyridone (7)--_-A mixture of PPA (10 g) and the amide $1(2.0 \mathrm{~g})$ was heated at $110-120^{\circ}$ with stirring for $2 \mathrm{hr}$. The reaction mixture was poured onto ice and extracted with AcOEt. The extract was dried over $\mathrm{Na}_{2} \mathrm{SO}_{4}$ and concentrated. The residue was recrystallized from acetone to afford $0.14 \mathrm{~g}(8 \%)$ of product 7 as needles, $\mathrm{mp} 258-260^{\circ}$ (dec.), which gave an IR spectrum identical with that of an authentic sample. ${ }^{14}$

Acknowledgement The present work was supported in part by a Grant-in-Aid for Scientific Research from the Ministry of Education, Science and Culture, Japan, which is gratefully acknowledged. Thanks are due to Mrs. C. Koyanagi and Miss K. Mushiake for elemental analyses.

13) J.N. Collie, J. Chem. Soc., 71, 299 (1897).

14) S. Seto, H. Sasaki, and K. Ogura, Bull. Chem. Soc. Jpn., 39, 281 (1966).

[Chem. Pharm. Bull.

\title{
Activation of N-Hydroxy Compounds by P-O Bond Formation through Anodic Oxidation of Triphenylphosphine
}

\author{
Hidenobu Ohmori, Shiro Nakai, and Masaichiro Masui \\ Faculty of Pharmaceutical Sciences, Osaka University1)
}

(Received February 7, 1980)

\begin{abstract}
Controlled potential electrolyses of triphenylphosphine (TPP) in acetonitrile containing an excess of $\mathrm{N}$-hydroxy compounds such as ketoximes, aldoximes, and hydroxamic acids were examined: subsequent treatment of the products under mild conditions gave amides, nitriles, and ureas, respectively. Electrolyses under conditions where the amounts of TPP were equal to or larger than those of the N-hydroxy compounds did not give satisfactory results.
\end{abstract}

Keywords-anodic oxidation; controlled potential electrolysis; triphenylphosphine; Beckmann rearrangement; phosphonium ions

Recently several investigators have reported modifications of the Beckmann rearrangement using organophosphorus compounds such as hexamethylphosphoric triamide ${ }^{2)}$ and $\mu$ oxo-bis[tris (dimethylamino)-phosphonium]-bis-tetrafluoroborate, ${ }^{3)}$ where ketoximes are activated by $\mathrm{P}-\mathrm{O}$ bond formation. In the rearrangement induced by the phosphonium ion, it is emphasized that the reaction can be effected under mild conditions. ${ }^{3)}$ The formation of alkoxyphosphonium salts in the anodic oxidation of triphenylphosphine (TPP ${ }^{4}$ ) suggested

1) Location: 133-1 Yamadakami, Suita, Osaka, 565 Japan.

2) N.O. Vesterager, E.B. Pederson, and S.O. Lawesson, Tetrahedron, 30, 2509 (1974) ; R.S. Monson and B.M. Broline, Can. J. Chem., 51, 942 (1973).

3) I.J. Galpin, P.E. Gordon, R. Ramage, and W.D. Thorpe, Tetrahedron, 32, 2417 (1976).

4) H. Ohmori, S. Nakai, M. Sekiguchi, and M. Masui, Chem. Pharm. Bull., 28, 910 (1980). 
the possibility of an electrochemical modification of the rearrangement. The conditions for such anodic oxidation would be mild as those of the method using the phosphonium-bistetrafluoroborate. ${ }^{3)}$

This paper reports the results of controlled potential electrolysis of TPP in the presence of ketoximes and related compounds in acetonitrile at a graphite electrode.

\section{Results and Discussion}

In acetonitrile containing $0.1 \mathrm{~m}$ sodium perchlorate, TPP showed a single, irreversible anodic peak at $1.0 \mathrm{~V}$ vs. S.C.E., as reported previously.4,5) The peak current of TPP increased on addition of various oximes (Table I), indicating the possibility of an anodic substitution reaction as in the oxidation of TPP with added nucleophiles such as alcohols ${ }^{4}$ and primary amines.5) The oximes showed ill-defined, drawn-out anodic peaks at potentials higher than $1.0 \mathrm{~V}$ : the voltammetric results are included in Table I.

Table II summarizes the results of controlled potential electrolysis of TPP in the presence of oximes and hydroxamic acids. Since the immediate products of the electrolysis (see below)

TABLE I. Results of Cyclic Voltammetry of TPP $(2.5 \mathrm{~mm})$ in the Presence of Various Oximes $\left.(5 \mathrm{~mm})^{a}\right)$

\begin{tabular}{lcccc}
\hline \multicolumn{1}{c}{ Additive } & $\begin{array}{c}\text { Peak } \\
\text { potential } \\
\text { (V vs. S.C.E.) }\end{array}$ & $\begin{array}{c}\text { Peak } \\
\text { current } \\
(\mu \mathrm{A})\end{array}$ & $\begin{array}{c}\text { Peak } \\
\text { potential } b) \\
(\text { V vs. S.C.E.) }\end{array}$ & $\begin{array}{c}\text { Peak } \\
\text { current } \\
(\mu \mathrm{A})\end{array}$ \\
\hline None & 1.00 & 21.0 & & \\
$\mathrm{Ph}_{2} \mathrm{C}=\mathrm{NOH}$ & 1.03 & 27.2 & 1.45 & 29.1 \\
$E-\mathrm{PhC}(\mathrm{Me})=\mathrm{NOH}$ & 1.07 & 32.5 & 1.30 & 25.0 \\
$\mathrm{Me}_{2} \mathrm{C}=\mathrm{NOH}$ & 1.07 & 46.9 & 1.61 & 25.3 \\
$\mathrm{Cyclo}-\mathrm{C}_{6} \mathrm{H}_{10}=\mathrm{NOH}$ & 1.01 & 48.0 & 1.70 & 29.5 \\
$\alpha-\mathrm{PhCH}=\mathrm{NOH}$ & 1.10 & 25.2 & 1.30 & 21.1 \\
$\alpha-\mathrm{C}_{3} \mathrm{H}_{7} \mathrm{CH}=\mathrm{NOH}$ & 1.03 & 43.0 & 1.90 & 21.3 \\
\hline
\end{tabular}

a) In acetonitrile containing $0.1 \mathrm{M} \mathrm{NaClO}_{4}$ using a glassy carbon electrode: voltage scan rate, $50 \mathrm{mV} \mathrm{s}^{-1}$; geometric electrode area, $0.071 \mathrm{~cm}^{2}$.

b) Voltammetric results obtained for the oximes themselves $(2.5 \mathrm{~mm})$.

TABLE II. Results of Controlled Potential Electrolysis of TPPa)

\begin{tabular}{|c|c|c|c|c|c|}
\hline $\begin{array}{l}\text { Run } \\
\text { No. }\end{array}$ & $\begin{array}{l}\text { Amount of } \\
\operatorname{TPP}(\mathrm{mmol})\end{array}$ & $\begin{array}{l}\text { Additive } \\
\text { (mmol) }\end{array}$ & $\begin{array}{l}\text { Applied } \\
\left.\text { potential }^{b}\right)\end{array}$ & $n$-Value & $\begin{array}{l}\text { Final product identified } \\
(\% \text { yeild })^{c)}\end{array}$ \\
\hline 1 & 2.0 & $\mathrm{Me}_{2} \mathrm{C}=\mathrm{NOH}$ & 1.00 & 2.11 & MeCONHMe $(82)^{d)}$ \\
\hline 2 & 2.0 & Cyclo- $\mathrm{C}_{6} \mathrm{H}_{10}=\mathrm{NOH}(6.6)$ & 3) 1.07 & 2.26 & $\varepsilon$-Caprolactam $(34)^{d)}$ \\
\hline 3 & 0.5 & $\mathrm{Ph}_{2} \mathrm{C}=\mathrm{NOH}(1.1)$ & 1.00 & 1.14 & $\left.\left.\mathrm{PhCONHPh}(49)^{e}\right) \mathrm{Ph}_{3} \mathrm{P}^{+} \mathrm{HClO}_{4}^{-}(19)^{f}\right)$ \\
\hline 4 & 0.6 & $\mathrm{Ph}_{2} \mathrm{C}=\mathrm{NOH}(2.1)$ & 1.00 & 1.29 & $\mathrm{PhCONHPh}(54)^{e)}$ \\
\hline 5 & 0.5 & $E-\mathrm{PhC}(\mathrm{Me})=\mathrm{NOH}(1.1)$ & 1.05 & 1.65 & $\mathrm{MeCONHPh}(52)^{e)} \mathrm{Ph}_{3} \mathrm{P}+\mathrm{HClO}_{4}^{-g)}$ \\
\hline 6 & 0.6 & $E-\mathrm{PhC}(\mathrm{Me})=\mathrm{NOH}(2.1)$ & 1.05 & 1.90 & MeCONHPh $(69)^{e)}$ \\
\hline 7 & 0.6 & $E-\mathrm{PhC}(\mathrm{Me})=\mathrm{NOH}(4.4)$ & 1.05 & 1.94 & MeCONHPh $\left.(93)^{e}\right)$ \\
\hline 8 & $1.0^{h)}$ & $\alpha-\mathrm{C}_{3} \mathrm{H}_{7} \mathrm{CH}=\mathrm{NOH}(5.7)$ & 1.05 & 2.63 & $\mathrm{C}_{3} \mathrm{H}_{7} \mathrm{CN}(99)^{d)}$ \\
\hline 9 & $0.9^{h)}$ & $\alpha-\mathrm{PhCH}=\mathrm{NOH}(4.1)$ & 1.05 & 1.28 & $\mathrm{PhCN}(99)^{d)} \mathrm{Ph}_{3} \mathrm{P}+\mathrm{HClO}_{4}-(37)^{f)}$ \\
\hline 10 & 2.0 & PhCONHOH (4.3) & 1.05 & 1.99 & $\left.\mathrm{PhNHCONHPh}^{\circ}(22)^{e>} \mathrm{Ph}_{3} \mathrm{P}^{+} \mathrm{HClO}_{4}^{-}(32)^{f}\right)$ \\
\hline 11 & 2.2 & MeCONHOH (5.9) & 1.05 & 2.18 & MeNHCONHMe $(14)^{i)} \mathrm{Ph}_{3} \mathrm{P}^{+} \mathrm{HClO}_{4}^{-g)}$ \\
\hline
\end{tabular}

a) In acetonitrile $(40 \mathrm{ml})$ containing $0.2 \mathrm{M} \mathrm{NaClO}_{4}$ : an $\mathrm{H}$-type electrolysis cell was used throughout with a graphite plate as the anode and a stainless steel plate as the cathode. $b$ ) V vs. S.C.E. $c$ ) Based on TPP used. $d$ ) Determined by GLC. e) Determined by HPLC. $f$ ) Isolated as TPP. $g$ ) The yield was not determined. $h$ ) In $10 \mathrm{ml}$ of acetonitrile containing $0.2 \times \mathrm{NaClO}_{4}$, i) Based on the isolated product after recrystallization.

5) H. Ohmori, S. Nakai, and M. Masui, J. Chem. Soc. Perkin I, 1978, 1333. 
were expected to be unstable, no attempt was made to isolate them; they were converted to the final products listed in Table II. Details of the procedures and identification of the products are described in the experimental section.

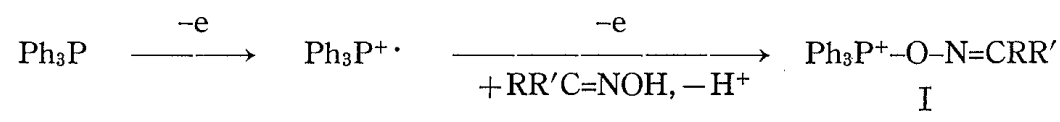

Chart 1

The formation of carboxamides from the ketoximes suggests that the phosphonium ion (I) is the product of the electrolysis. Thus, the electrochemical process can be represented as in Chart 1 by analogy with other anodic substitution reactions of TPP.4-6) The proton liberated in the electrolysis will be accepted by $\mathrm{TPP}^{4,6)}$ and/or the ketoximes, and the coulometric $n$-value will depend on the basicity and the amount of a particular ketoxime (see Run Nos. $1-7$ in Table II). With a small amount of weakly basic ketoxime the $n$-value will approach unity and half of the starting TPP will be recovered as its protonated form. ${ }^{7}$ In the reverse situation the $n$-value will be two and all of the TPP will be oxidized to give the corresponding phosphonium ion (I). ${ }^{7}$ These considerations are reflected in the voltammetric peak height of TPP in the presence of the oximes (Table I). ${ }^{8}$

The results of electrolysis in the presence of butyraldoxime (Run No. 8 in Table II) together with the corresponding voltammetric behavior (Table I) suggest that the phosphonium ion ( $\mathrm{I} ; \mathrm{R}=\mathrm{C}_{3} \mathrm{H}_{7}, \mathrm{R}^{\prime}=\mathrm{H}$ ) is formed according to the process in Chart 1 . In the electrolysis with benzaldoxime (Run No. 9), however, the yield of benzonitrile is too high as judged from the coulometric $n$-value and the amount of $\mathrm{Ph}_{3} \mathrm{P}^{+} \mathrm{H}$ isolated. Some process other than that described above must also be involved in the nitrile formation. When benzaldoxime (4.0 $\mathrm{mmol}$ ) was refluxed for $3 \mathrm{hr}$ in acetonitrile $(10 \mathrm{ml})$ containing (a) $\mathrm{Ph}_{3} \mathrm{P}^{+} \mathrm{HClO}_{4}{ }^{-}(0.88 \mathrm{mmol})$, (b) $\mathrm{HClO}_{4}(1.27 \mathrm{mmol})$, and (c) $\mathrm{HClO}_{4}(1.05 \mathrm{mmol})$ and $\mathrm{NaClO}_{4}(1 \mathrm{~g})$, benzonitrile was formed in yields of (a) 99 , (b) 90 , and (c) $91 \%$, based on the acids employed. However, when the reaction was carried out with equimolar amounts of benzaldoxime and the catalysts, the yield of the nitrile decreased to $40-60 \%$. Although no clear-cut explanation can be given for these results, it seems plausible that an acid-catalyzed, probably $\mathrm{Ph}_{3} \mathrm{P}^{+} \mathrm{H}$-catalyzed, dehydration of the oxime took place together with the electrochemically catalyzed dehydration. In the case of the ketoximes, no rearrangement product was detected under the non-electrolytic conditions described above.

The results for electrolysis in the presence of hydroxamic acids (Run Nos. 10 and 11) can be explained in the same way as for electrolysis with weakly basic ketoximes (Run Nos. 3 and 4). The ureas will be formed from the phosphonium ion (II) via a process similar to that suggested in the phosphonium-bis-tetrafluoroborates-induced rearrangement of phenylhydroxamic acid. ${ }^{3)}$ The coulometric $n$-values were considerably larger than unity, probably because some of the hydroxamic acids were oxidized at the anode potential applied: the anodic discharge potentials of the hydroxamic acids were very close to that of TPP under the experimental conditions used.

\section{$\mathrm{R}-\mathrm{CONH}-\mathrm{O}-\mathrm{P}^{+} \mathrm{Ph}_{3}$}

II

As shown in Table II the electrolyses were carried out with amounts of the oximes and the hydroxamic acids larger than that of TPP, and only a fraction of the particular N-hydroxy

6) G. Schiavon, S. Zecchin, G. Cogoni, and G. Bontempelli, J. Electroanal. Chem., 48, 425 (1973).

7) These arguments are valid only for a run in which the ketoxime is in excess over TPP.

8) The maximum value for the ratio of the peak current of TPP in the presence of the oximes to that in the absence of the oximes is three (ref. 5). 
compound was converted to the final product. Electrolyses in acetonitrile under various conditions $^{9)}$ with an amount of TPP equal to or larger than that of acetoxime were tried in an attempt to improve the yield of $\mathrm{N}$-methylacetamide, but a satisfactory result was not obtained. For the synthetic application of this electrochemical modification of Beckmann rearrangement, further investigation is required.

\section{Experimental}

Materials__ TPP was recrystallized from $n$-hexane and stored over phosphorus pentoxide under reduced pressure. Sodium perchlorate and acetonitrile were purified as described previously. ${ }^{5}$ ) Oximes and hydroxamic acids were prepared by standard procedures. All other chemicals were of reagent grade and were used without further purification.

Apparatus-Cyclic voltammetry and controlled potential electrolysis were carried out essentially as described previously. ${ }^{10)}$ IR and PMR spectra were obtained using Hitachi EPI-2 and R-20A spectrometers, respectively. GLC was carried out using a Nihondenshi JGC-20K gas chromatograph connected with a Takeda Riken TR-2215A digital integrator: PEG 20M was used as packing. HPLC was carried out using a Waters 6000-A solvent delivery system with a U6K universal injector and a JASCO UVIDEC-1 spectrometer: Bondapack $\mathrm{C}_{18}$-Corasil; $40 \%$ aqueous methanol.

Controlled. Potential Electrolysis__Electrolyses were performed in an H-type divided cell5) with a graphite plate as the anode and a stainless steel plate as the cathode. Typical examples of the procedure are described below.

(a) Electrolysis in Acetonitrile containing Acetoxime: A solution of TPP (2.0 mmol) and acetoxime $(11.3 \mathrm{mmol})$ in acetonitrile $(40 \mathrm{ml})$ containing $0.2 \mathrm{M} \mathrm{NaClO}_{4}$ was placed in the anode compartment, and acetonitrile $(40 \mathrm{ml})$ containing $0.2 \mathrm{M} \mathrm{NaClO}_{4}$ in the cathode compartment. The system was subjected to electrolysis at $1.0 \mathrm{~V}$ vs S.C.E. until the current fell below $2 \%$ of the initial value (ca. $80 \mathrm{~min})$. From the currenttime curve, $414.3 \mathrm{C}$, which corresponded to $n=2.11$, was found to have been consumed. The electrolyzed solution was evaporated to dryness under reduced pressure and the residue was extracted with chloroform $(3 \times 20 \mathrm{ml})$. After removing the chloroform under reduced pressure, the residue was refluxed in a mixture of water $(10 \mathrm{ml})$ and acetonitrile $(5 \mathrm{ml})$ for $1 \mathrm{hr}$. A little of the resulting solution was used to estimate the yield of the Beckmann rearrangement product by GLC (see Table II). The remainder was evaporated to dryness under reduced pressure. The residue was subjected to column chromatography first on silica gel with chloroform-methanol $(50: 1)$ as an eluant, and then on neutral alumina with benzene-methanol (10:1). $\mathrm{N}$-Methylacetamide was obtained as a colorless oil, whose IR and PMR spectra coincided with those of an authentic sample.

(b) Electrolysis in the Presence of Butyraldoxime: TPP (1.0 mmol) in acetonitrile containing butyraldoxime $(5.7 \mathrm{mmol})$ and $0.2 \mathrm{M} \mathrm{NaClO}_{4}$ was electrolyzed similarly at $1.05 \mathrm{~V}$ until the voltammetric peak due to TPP disappeared (ca. $90 \mathrm{~min}$ ). The electrolyzed solution was refluxed for $3 \mathrm{hr}$. The resulting solution was analyzed by GLC to estimate the yield of the dehydration product, butyronitrile (see Table II).

(c) Electrolysis in the Presence of Benzhydroxamic Acid: A solution of TPP (2.0 mmol) and benzhydroxamic acid $\left(4.25 \mathrm{mmol}\right.$ ) in acetonitrile containing $0.2 \mathrm{M} \mathrm{NaClO}_{4}$ was electrolyzed as described in (b) (ca. $110 \mathrm{~min})$. The electrolyzed solution was evaporated to dryness under reduced pressure and the residue was extracted with chloroform $(3 \times 20 \mathrm{ml})$. After removing the chloroform under reduced pressure, the residue was refluxed in a mixture of water $(1 \mathrm{ml})$, acetonitrile $(10 \mathrm{ml})$, and triethylamine $(0.5 \mathrm{ml})$ for $1 \mathrm{hr}$. A little of the resulting solution was used to estimate the yield of the Lossen-type rearrangement product by HPLC (see Table II). The remainder was worked up by column chromatography as described in (a) to obtain diphenylurea as a colorless amorphous solid; mp 239-240 $\left.\left(1 \mathrm{it} .{ }^{2}\right) 238-240^{\circ}\right)$. The IR and the PMR spectra of the product coincided with those of an authentic sample.

9) Electrolyses were carried out not only in the two-compartment cell used to obtain the results in Table II, but also in a one-compartment cell with and without added bases such as $\mathrm{K}_{22} \mathrm{CO}_{3}$ or 2,6-lutidine. Constant current electrolysis was also examined.

10) H. Sayo and M. Masui, J. Chem. Soc. Perkin I, 1973, 1640. 